OPEN ACCESS

Edited by:

Babita Agrawal,

University of Alberta, Canada

Reviewed by:

Sampa Santra,

Beth Israel Deaconess Medical Center and Harvard Medical School, United States Richard Kennedy, Mayo Clinic, United States

*Correspondence:

Chrysanthi Skevak

chrysanthi.skevaki@uk-gm.de

Specialty section:

This article was submitted to Vaccines and Molecular Therapeutics,

a section of the journal

Frontiers in Immunology

Received: 22 December 2019 Accepted: 06 March 2020

Published: 31 March 2020

Citation:

Balz K, Trass/ L, Härtel V, Nelson PP and Skevaki C (2020) Virus-Induced T Cell-Mediated Heterologous Immunity and Vaccine Development.

Front. Immunol. 11:513.

doi: 10.3389/fimmu.2020.00513

\section{Virus-Induced T Cell-Mediated Heterologous Immunity and Vaccine Development}

\author{
Kathrin Balz, Lilith Trassl, Valerie Härtel, Philipp P. Nelson and Chrysanthi Skevaki* \\ German Center for Lung Research (DZL), Institute of Laboratory Medicine, Universities of Giessen and Marburg Lung Center \\ (UGMLC), Philipps University Marburg, Marburg, Germany
}

Heterologous immunity (H.I.) is a consequence of an encounter with a specific antigen, which can alter the subsequent immune response to a different antigen. This can happen at the innate immune system level-often called trained immunity or innate immune memory-and/or at the adaptive immune system level involving $T$ memory cells and antibodies. Viruses may also induce T cell-mediated H.I., which can confer protection or drive immunopathology against other virus subtypes, related or unrelated viruses, other pathogens, auto- or allo-antigens. It is important to understand the underlying mechanisms for the development of antiviral "universal" vaccines and broader T cell responses rather than just subtype-specific antibody responses as in the case of influenza. Furthermore, knowledge about determinants of vaccine-mediated H.I. may inform public health policies and provide suggestions for repurposing existing vaccines. Here, we introduce H.I. and provide an overview of evidence on virus- and antiviral vaccine-induced $T$ cell-mediated cross-reactive responses. We also discuss the factors influencing final clinical outcome of virus-mediated H.I. as well as non-specific beneficial effects of live attenuated antiviral vaccines such as measles and vaccinia. Available epidemiological and mechanistic data have implications both for the development of new vaccines and for personalized vaccinology, which are presented. Finally, we formulate future research priorities and opportunities.

Keywords: cross-protection, immune memory, molecular mimicry, TCR repertoire, $\mathrm{T}$ cell epitope, virus-induced immunity, immunopathology, immunomodulation

\section{INTRODUCTION}

Heterologous immunity (H.I.) arises from previous infections, which alter the immune response to a subsequent infection with a different pathogen (1). This mechanism is more likely to occur between closely related antigens, but may also occur among unrelated antigens, including bacteria, viruses, protozoa, and parasites. H.I. may alter the outcome of infections by providing sufficient immune protection or, in other cases, aggravating immunopathology (2).

H.I. is mediated by $\mathrm{T}$ memory cells or antibodies (Figure 1). Immunoglobulins recognize antigens when antigenic epitopes attach to paratopes (Table 1) at the antigen-binding site. Antibodies are potentially polyspecific, capable of binding different epitopes to various antigens. Furthermore, epitopes sharing similar sequences may bind to the same paratope, providing crossprotection (4). In the context of molecular mimicry, antibodies may also react to self-antigens, eliciting autoreactive immunopathology (5). 


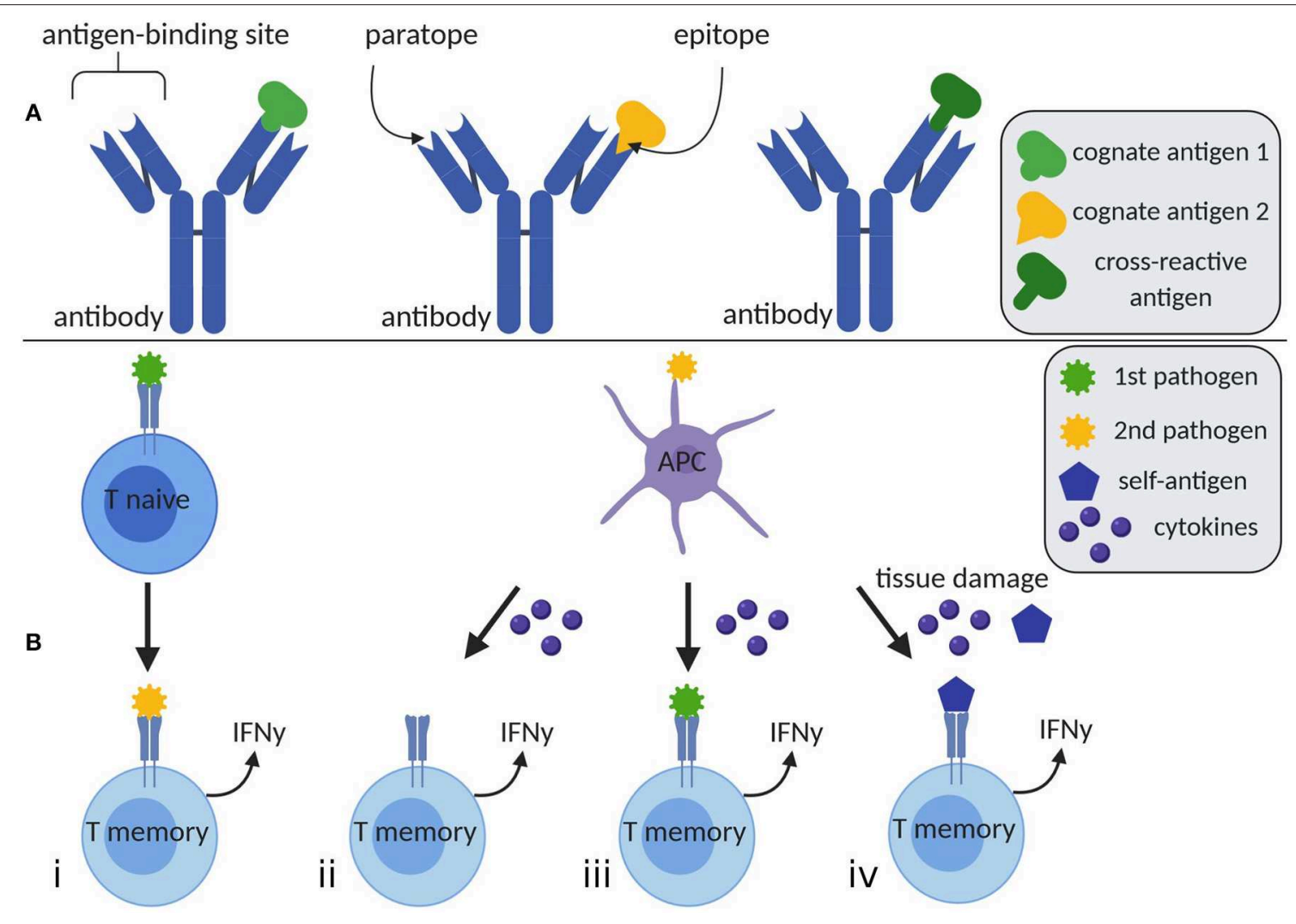

FIGURE 1 | Humoral and cellular mediated heterologous immunity. (A) A single antibody has the ability to bind distinct antigens 1 and 2 by different paratopes at the antigen-binding site. Furthermore, it is able to detect a cross-reactive antigen, whose epitope is similar to the one of antigen 1. (B) (i) T memory cells may be activated by an unrelated second pathogen, which is cross-reactive with the first encountered pathogen. (ii) The appearance of a second pathogen may elevate cytokine levels, which potentially lead to TCR-independent T cell activation. (iii) Simultaneous presence of cytokines and remaining antigens of previously encountered pathogens may stimulate T cells. (iv) High levels of cytokines and tissue damage due to inflammation or chronic diseases result in increased concentrations of self-antigens, which may be engaged by T cells. Created with BioRender.com, adapted from Welsh et al. (3). APC, antigen presenting cell; IFN $\gamma$, interferon $\gamma$.

Likewise, cellular-mediated H.I. plays a role in immunomodulation. This may be elicited via $\mathrm{T}$ cell receptor (TCR) cross-reactivity (one possible mechanism of H.I.), recognizing similar but distinct antigens or even autoantigens. $\mathrm{T}$ cells may also be activated non-specifically by cytokines [reviewed in (3)]. Cross-reactive antigens elicit an expansion of $\mathrm{T}$ memory cells, leading to a modified $\mathrm{T}$ cell memory pool, a change in patterns of immunodominance, and an altered hierarchy of $\mathrm{T}$ cell responses (6). This process heavily depends on the individual private specificities of TCR repertoires and ultimately results in a modified $\mathrm{T}$ cell response (7).

Trained immunity, also known as innate immune memory, is a recently described adaptation of innate immune cells following antigenic exposure. Epigenetic reprogramming leads to production of inflammatory mediators and a shift in cellular metabolism, providing an enhanced response to secondary stimulation [reviewed in (8)]. Thus, physiological processes such as mucosal tolerance, restriction of tissue damage, innate immunity maturation, and non-specific vaccine-mediated protection are achieved. Nevertheless, trained immunity can become maladaptive, causing immune paralysis or hyperinflammation [reviewed in (9)].
This review presents recent scientific findings regarding virusor antiviral vaccine-induced $\mathrm{T}$ cell-mediated H.I. and thus provides some background for the discussion on benefits and risks of H.I. Implications for future research priorities for vaccine development are also considered.

\section{VIRUS- AND ANTIVIRAL VACCINE-INDUCED T CELL-MEDIATED HETEROLOGOUS IMMUNITY}

\section{Influenza Virus}

Naïve T cells of donors who self-reported as having no influenza A Virus (IAV) H1N1/09 exposure or influenza symptoms can recognize unique strain-specific epitopes using tetramer staining, whereas the same donors' memory $\mathrm{T}$ cells recognize conserved epitopes of the surface protein hemagglutinin (HA) (10). In H1N1/09 infected or vaccinated donors, the frequency of naïve $\mathrm{T}$ cells recognizing unique epitopes was significantly higher compared to conserved epitope-specific T cells (10). This has also been shown for $\mathrm{CD}^{+}(10)$ and $\mathrm{CD}^{+} \mathrm{T}$ cells in mice (11).

Such observations suggest that H.I. influences the severity of infection (10). An age-related dampening of T-cell mediated 


\begin{tabular}{|c|c|}
\hline Heterosubtypic & $\begin{array}{l}\text { Referring to different serotypes of influenza A virus, which } \\
\text { are defined based on the surface proteins hemagglutinin } \\
(\mathrm{HA}) \text { and neuraminidase }(\mathrm{NA}) \text {. }\end{array}$ \\
\hline HLA molecule & $\begin{array}{l}\text { The human leucocyte antigen is located on cell surfaces } \\
\text { and may present antigenic peptides to T cells. }\end{array}$ \\
\hline Immunodominance & $\begin{array}{l}\text { Only a few (immunodominant) epitopes are preferentially } \\
\text { targeted by the immune response. The remaining epitopes } \\
\text { evoke barely detectable } T \text { cell responses. }\end{array}$ \\
\hline Molecular mimicry & $\begin{array}{l}\text { An alignment of pathogenic structures with those of the } \\
\text { host, which leads to immune evasion. However, structure } \\
\text { similarity of pathogens and self-antigens may elicit } \\
\text { autoreactive immune responses. }\end{array}$ \\
\hline Paratope & $\begin{array}{l}\text { A segment of an antibody's antigen-binding site, which } \\
\text { complementarily binds an epitope. }\end{array}$ \\
\hline $\begin{array}{l}\text { Private specificity of } \\
\text { TCR repertoire }\end{array}$ & TCR repertoires, which are different among individuals. \\
\hline TCR repertoire & All T cell receptor clonotypes expressed by an organism. \\
\hline
\end{tabular}

H.I. was observed following a second heterologous infection in ferrets, which allowed the development of significant morbidity (12). These findings are in agreement with other studies focusing on aged animals, which showed that the clinical severity of primary infection is only moderately accentuated (13-16), while heterologous secondary infection induced severe disease (12, $17,18)$. The induction of influenza virus-specific memory $\mathrm{T}$ cells is extensively investigated as they are responsible for heterologous protection in secondary natural infections with another influenza strain [reviewed in (19)]. Tissue resident memory $\mathrm{T}$ cells $\left(\mathrm{T}_{\mathrm{rm}}\right)$ in the lung are particularly important in that respect as they are crucial for achieving optimal protection [reviewed in (19)]. Previous animal studies showed that a single intranasal live attenuated IAV vaccine application can evoke long-lasting protection to heterosubtypic challenge via $\mathrm{T}_{\mathrm{rm}}$ response in the lung with a similar phenotype to those of infected mice (20). Several in silico approaches are available to identify $\mathrm{T}$ cell immunogenic regions on virus proteins. It has been demonstrated that epitope-rich regions within the nucleoprotein (NP) of the influenza virus contain highly conserved epitopes and therefore present promising targets for a $\mathrm{T}$ cell-mediated vaccine due to cross-reactivity with distinct strains (21). Gutiérrez et al. developed a computational method to compare the efficacy of conserved $\mathrm{T}$ cell epitopes (EpiCC), which may complement current methods for selecting the best composition of an associated vaccine (22). Furthermore, $\mathrm{CD} 8^{+} \mathrm{T}$ cells recognizing different NP variants were associated with cross-reactive TCR clonotypes against distinct strains (23). This was shown for the immunodominant and abundant human epitopes $\mathrm{NP}_{338-346}$ and $\mathrm{NP}_{44-52}$ (23). A structural analysis of the associated HLA molecules revealed adoption of similar conformation as a basis for cross-recognition (23).

Spleen cells from IAV-infected animals showed enhanced IFN $\gamma$ production after ex vivo stimulation with the hepatitis $\mathrm{C}$ virus (HCV) derived peptide $\mathrm{NS}_{1073}$ (24). Such findings suggest a private repertoire of pre-existing memory $\mathrm{T}$ cells, which are reactivated after HCV infection (25). Cross-reactivity was also demonstrated in human peripheral blood mononuclear cells (PBMCs) of HCV positive patients with severe disease which responded to the IAV-specific peptide $\mathrm{NA}_{231-239}$ (25). Additionally, PBMCs of hepatitis B virus patients were incubated with Epstein-Barr virus EBV-BMLF1 $1_{280-288}$ and IAV-M1 $1_{58-66}$ labeled tetramers and subsequently stained for TCR clones (26). The TCR repertoire of cross-reactive $\mathrm{T}$ cells recognizing IAV and EBV epitopes was broader compared to non-cross-reactive T cells and varied among individuals, further supporting an underlying private specificity (26). The concept of H.I. has recently been expanded to include allergens, following demonstration of IAV-mediated protection against allergen-induced experimental asthma (mediated by memory T cells) in a murine model (27).

\section{Flaviviruses}

The high degree of genetic sequence similarity among flaviviruses is known either to have a protective effect or to dampen the elicited secondary immune response [reviewed in (28)]. For Dengue virus (DENV), it is well-known that an infection with one serotype induces strong and long-lasting protective immunity against that specific serotype, whereas a second infection with a heterotypic virus commonly results in severe disease [reviewed in (29)]. Sub-neutralizing antibody concentrations from the first infection facilitate virus entry by promoting $\mathrm{F} c \gamma$-receptor uptake, resulting in antibodydependent enhancement (ADE) of the infection. However, there is increasing evidence of a cross-protective cellular immune response between DENV and Zika virus (ZIKV) [reviewed in (29)]. Memory T cells isolated from DENV seropositive patients recognize both DENV- and ZIKV-associated peptides (30). Furthermore, DENV positive patients responded more strongly to a ZIKV infection compared to DENV negative subjects when assessed using $\mathrm{T}$ cell stimulation assays $(30,31)$. Mouse experiments have also shown, that DENV-exposed pregnant animals were protected against subsequent maternal and fetal ZIKV infection (32). This protection was conferred by $\mathrm{CD} 8^{+}$ $\mathrm{T}$ cells, limiting trans-placental transmission of ZIKV (32). Although cross-reactivity between DENV and ZIKV is the most prominent example, other flaviviruses, such as yellow fever virus (YFV) and Japanese encephalitis virus, also prime $\mathrm{T}$ cell responses toward a subsequent heterologous DENV infection in mice (33). In this context, the investigators identified homologous sequences between the flavivirus polyproteins. Peptides derived from the aforementioned sequences were used to prime antigen presenting cells, which were subsequently used to stimulate splenocytes of DENV immunized mice. Some of these peptides induced enrichment of $\mathrm{T}$ memory cells as well as IFN $\gamma$ production and proliferation, confirming cross-reactivity (33).

\section{Human Immunodeficiency Virus}

Human immunodeficiency virus 1 (HIV-1)-specific $\mathrm{CD}^{+}{ }^{+} \mathrm{T}$ cell clones showed cross-reactivity against some of the other investigated HIV-1 epitopes (34). Additionally, three HIV-1specific $\mathrm{T}$ cell clones recognized the $\mathrm{A}^{*} 02$ restricted IAV matrix epitope GILGFVFTL (34). Furthermore, a sequence similarity between the known HIV-1 epitope HIV-Gag [SLYNTVATL [HIV-SL9]] and the HCV epitope HCV-NS5b [ALYDVVSKL 
[HCV-AL9]] has been observed. HIV-SL9 specific T cells of HIV-1 patients, who were not co-infected with HCV, recognized the aforementioned HCV epitope and responded with IFN $\gamma$ production and expansion (35).

\section{Hepatitis C Virus}

Cross-genotype protective immunity against $\mathrm{HCV}$ was first described in 2003 by Lanford et al. who showed that chimpanzees, which recovered from a genotype 1 infection, were subsequently protected from infection with other genotypes (including genotype 4 and combinations of genotypes 1-4). These genotypes express proteins of up to $30 \%$ amino acid variance (36). This finding, however, has been challenged by other investigators who showed that chimpanzees developed chronic disease after being re-challenged with other genotypes (37).

CD8 ${ }^{+} \mathrm{T}$ cell cross-reactivity to NS3 epitopes of two different genotypes ( 1 and 3 ) was observed in a study with 53 anti$\mathrm{HCV}$ positive injection drug users. Interestingly, $\mathrm{CD}^{+}{ }^{+} \mathrm{T}$ cells recognizing both genotypes were more frequent among $\mathrm{HCV}$ RNA negative patients than in those with detectable viremia, implying that $\mathrm{CD} 8^{+} \mathrm{T}$ cell-mediated cross-reactivity may protect against chronic infection (38).

In another study, an HLA-restricted epitope (HCV NS3-1406) and its naturally occurring variants from different genotypes showed that the frequency of cross-reactivity between variants as well as their $\mathrm{T}$ cell priming capacities varied, depending on the genotype pair (39). Fytili et al. performed a similar study for another dominant HLA-dependent HCV $\mathrm{CD}^{+}{ }^{+} \mathrm{T}$ cell epitope (HCV NS3-1073), which was associated with clearance of acute infection, and detected cross-reactivity between the genotype 1 variant and variants of genotypes 4, 5, and 6 but not 2 and 3 (40). The level of cross-reactivity observed in this study could be predicted through in silico analyses of peptide-MHC complexes and TCR-interacting surfaces based on topology and electrostatic features (41).

The same dominant T cell epitope (HCV NS3-1073) was also found to induce immune response in approximately a third of $>100$ seronegative individuals upon ex vivo stimulation. The presence of $\mathrm{CD}^{+} \mathrm{T}$ cells specific for that epitope was attributed to cross-reactivity with epitopes derived from other pathogens. These cells not only reacted to different genotype variants of that epitope but also to epitopes with little sequence similarity of other, unrelated viruses (cytomegalovirus, IAV, EBV) (42). Immunization with a recombinant adenovirus vector containing mycobacteria, Ebola and HIV antigens also led to T cell responses against HCV alongside the transgenic antigens (43). Crossreactivity between an HCV and a human herpes virus peptide has also previously been demonstrated (44).

\section{Other Viruses}

Severe hand, foot and mouth disease is caused among others by enterovirus 71 . A dominant capsid $\mathrm{T}$ cell epitope, which is highly conserved among enteroviruses, was identified and found to yield a cross-reactive, HLA-DR restricted response of human $\mathrm{CD}^{+} \mathrm{T}$ cells to the poliovirus variant of this epitope (45). Human RV-specific $\mathrm{CD}^{+} \mathrm{T}$ cells were shown to recognize epitopes shared among different $\mathrm{RV}$ strains (46). Human circulating RV-specific $\mathrm{CD} 4^{+} \mathrm{T}$ cells recognized conserved RV capsid protein epitopes, and $\mathrm{T}$ cell-mediated cross-reactivity between different strains was demonstrated (47). Zhao et al. showed that airway $\mathrm{CD}^{+} \mathrm{T}$ memory cells specific for a dominant, conserved epitope (SARS-N353) protect against both SARS- and MERS-CoVs and also against bat CoV in HLA transgenic murine models (48). Hepatitis $\mathrm{E}$ virus (HEV)-specific $\mathrm{CD}^{+}$and $\mathrm{CD}^{+} \mathrm{T}$ cell responses against different peptide pools from HEV1 were detected in acute HEV3 patients. A similar response against HEV3- and HEV1-peptide pools was detected in one subjectwith HEV1 infection (49). Finally, H.I. between the arenaviruses lymphocytic choriomeningitis virus and Pichinde virus was demonstrated in murine models and found to be $\mathrm{T}$ cell epitope and MHC class dependent (50).

\section{DISCUSSION}

\section{Protection vs. Immunopathology}

Overall, virus-induced H.I. appears to be an important determinant for the final outcome of infections and of a plethora of dysregulated immune responses such as in autoimmunity and allograft rejection. In this context, prior antigenic exposures may boost protective responses [e.g., (27)] or induce immunopathology depending on the balance between antigen load and efficiency of effector $\mathrm{T}$ cells, which in turn is influenced by a number of factors. For example, in the case of flaviviruses, it has recently become evident that distinct $\mathrm{T}$ cell populations, virus serotypes, sequence, and number of infections, and HLA background all shape the immunodominance pattern (29). Additionally, patterns of $\mathrm{T}$ cell cytokine response among patients with a secondary DENV infection were associated with severe $(51,52)$ or mild dengue $(53$, 54). Although heterotypic antigens were addressed only in one of these studies (52), such observations may indicate involvement of cross-reactive $\mathrm{T}$ cells in the clinical manifestation of DENV infections.

In addition to natural viral infections, antiviral vaccines may also drive $\mathrm{T}$ cell-mediated H.I. and have a major impact not only against the vaccine antigens but also on completely unrelated pathogens or other antigens. To date, epidemiological evidence supporting the role of live attenuated vaccines in $\mathrm{T}$ cell-mediated H.I. is associated with the measles (55$62)$, the vaccinia (63-66), and the oral polio vaccine (6769). These vaccines reduced overall mortality and/or risk for asthma, malignancies, and unrelated infections. Furthermore, they induced changes in the numbers or proportions of $\mathrm{T}$ and $\mathrm{B}$ cells, which, depending on persistence of effects, may influence differentiation, proliferation or survival of associated cells. Non-specific effects of vaccines have often been found to be sex-specific and influenced by revaccination as well as maternal priming. In this regard, knowledge on the potential of specific $\mathrm{T}$ cell epitopes (for any given HLA background) to offer protection or cause pathology is crucial for vaccine design including elimination or inclusion of such peptides. 


\section{Implications for Vaccine Development}

The ability to predict the magnitude and mechanism of $\mathrm{T}$ cell-mediated H.I. (Figure 1B) is crucial for specific vaccine design but also for decisions on public health and vaccination policies. Structural similarity between $\mathrm{T}$ cell epitopes seems to be important for eliciting cross-reactive responses. Nevertheless, seemingly distinct epitopes may also bind to the same TCR and induce H.I. This may be explained by the fact that sequence similarity is also dependent on the presence of biochemically similar amino acid substitutions (70). In the context of developing broadly cross-reactive vaccines against viruses with great antigenic heterogeneity, regions of highly conserved proteins among serotypes may elicit cross-reactive $\mathrm{T}$ memory cell responses. This approach along with large scale systematic monitoring of circulating strains, as in the case of influenza (in order to minimize mismatch with vaccinecontained strains) may increase vaccine effectiveness.

Besides their specific effect, it is now known that vaccines may also exert a non-specific influence on the immune system (71). For the diphtheria-tetanus-pertussis and measles vaccines, it was shown that the order of vaccination has an impact on overall morbidity and mortality (72). The concept that the most recently administered vaccine leaves a non-specific immunological imprint until subsequent immunization may guide changes in the recommended order of childhood vaccinations. Such changes could result in beneficial non-specific effects with minor changes of existing national vaccination schemes. Similarly, age at the time of (initial or booster) immunization with each existing vaccine may need to be reconsidered based on the accumulating knowledge on immunosenescence and effects of age on virusinduced H.I. Accordingly, time of vaccination has been linked to differences in $\mathrm{T}$ cell populations and strength and type of heterologous immune response $(73,74)$. Sex-specific differences in terms of protective non-specific effects of vaccines such as measles and vaccinia (64, 75-80) have also been described. Modification of vaccine composition (e.g., enrichment of particular proteins or epitopes) or conditions of administration (e.g., age, dose, number of immunizations) could potentially help us achieve the beneficial heterologous effects of vaccines without compromising their primary protective effects (vaccine specific). Indeed, adequate application of knowledge regarding vaccinemediated H.I. brings us a step closer to precision medicine and personalized vaccinology. Administration of live attenuated vaccines to women as part of preconception health counseling is another measure, which could enhance protection of offspring in the first months of life.

The potential of virus- and antiviral vaccine-induced immunomodulation may also be exploited for novel applications such as preventing infections among elderly and immunocompromised populations or non-infectious inflammatory diseases. In this respect, the choice of a particular adjuvant or pharmacological modulator is also important since these may polarize $\mathrm{T}$ cell immune responses toward a specific cytokine output depending on the desired outcome, e.g., induction of T1 type of response for prevention of infection as well as allergies.

\section{Future Research Priorities}

The need for new vaccines with higher efficacy and broader and longer-lasting protection is driven by the moderate protection provided by current seasonal influenza vaccines against the included strains, zoonotic and pandemic influenza threats, and the challenge of complying with annual vaccinations. Several approaches are currently being investigated with varying results and distance from truly universal vaccines. The use of adjuvants, addition of neuraminidase, and inclusion of specific strains induce broader reactive immune responses albeit within the same virus subtype. Additionally, immunogenic influenza HA-stem constructs induce B cells which produce cross-protective antibodies, at least within a group of viruses. A particular promising approach for the development of truly universal influenza vaccines seems to be the induction of $\mathrm{T}$ cells reactive to internal viral proteins, primarily of $\mathrm{T}_{\mathrm{rm}}$ in the respiratory mucosa for timely control of viral replication. Such approaches could also prove useful for developing vaccines against other respiratory viruses such as rhinoviruses. Similarly, knowledge gained from current studies of $\mathrm{T}$ cell responses against DENV/ZIKV infections at several time points, and with different clinical presentations and history of infection may inform strategies for developing pan-flavivirus vaccines. Indeed, there is already evidence for cross-reactive immunogenic epitopes contained in these viruses.

Properties of virus-induced H.I. may be leveraged beyond infection protection. We have previously shown an influenza virus-mediated protection over development of experimental asthma in a murine model. The protection was conferred by $\mathrm{CD}^{+}$and $\mathrm{CD}^{+} \mathrm{T}$ memory cells, which were transferred from animals previously infected with influenza or immunized with cross-reactive influenza peptides to sensitized mice before challenge with an allergen. Given the global prevalence of allergies, peptide immunization strategies early in life could potentially induce protective cellular immune responses against viruses and allergen-induced asthma, and complement existing vaccination schedules. Importantly, directing nonspecific beneficial effects of existing live attenuated viral vaccines against other inflammatory disorders including cardiovascular disease and cancer could be a quantum leap in the fight against non-communicable diseases $(65,81-84)$.

Further immunological and clinical studies are needed to decipher vaccine-induced H.I.-mediated mechanisms and impact on morbidity and mortality contributing to health promotion. Associated potentiators such as booster vaccinations and maternal priming need to be examined carefully in different socioeconomic settings and with a sex-differential analysis (85).

\section{AUTHOR CONTRIBUTIONS}

CS and PN planned, structured, and edited the manuscript. PN searched the literature and integrated all contributions. All authors wrote distinct parts of the manuscript and critically read, reviewed, and approved the final version of the manuscript. 


\section{FUNDING}

CS is supported by Universities Giessen and Marburg Lung Center (UGMLC), the German Center for Lung Research (DZL), the Rhön-Klinikum (UKGM), and the Deutsche Forschungsgemeinschaft (DFG)-funded-SFB 1021 (C04), -KFO 309 (P10), and SK 317/1-1 (Project number 428518790).

\section{REFERENCES}

1. Welsh RM, Selin LK. No one is naive: the significance of heterologous T-cell immunity. Nat Rev Immunol. (2002) 2:417-26. doi: 10.1038/nri820

2. Selin LK, Varga SM, Wong IC, Welsh RM. Protective heterologous antiviral immunity and enhanced immunopathogenesis mediated by memory $\mathrm{T}$ cell populations. J Exp Med. (1998) 188:1705-15. doi: 10.1084/jem.188.9.1705

3. Welsh RM, Che JW, Brehm MA, Selin LK. Heterologous immunity between viruses. Immunol Rev. (2010) 235:244-66. doi: 10.1111/j.0105-2896.2010.00897.x

4. van Regenmortel MH. Specificity, polyspecificity, and heterospecificity of antibody-antigen recognition. J Mol Recognit. (2014) 27:627-39. doi: 10.1002/jmr.2394

5. Barnett LA, Fujinami RS. Molecular mimicry: a mechanism for autoimmune injury. FASEB J. (1992) 6:840-4. doi: 10.1096/fasebj.6.3.1740233

6. Selin LK, Cornberg M, Brehm MA, Kim S-K, Calcagno C, Ghersi D, et al. CD8 memory T cells: cross-reactivity and heterologous immunity. Semin Immunol. (2004) 16:335-47. doi: 10.1016/j.smim.2004.08.014

7. Nie S, Lin S-J, Kim S-K, Welsh RM, Selin LK. Pathological features of heterologous immunity are regulated by the private specificities of the immune repertoire. Am J Pathol. (2010) 176:2107-12. doi: 10.2353/ajpath.2010.090656

8. Netea MG, van der Meer JW. Trained immunity: an ancient way of remembering. Cell Host Microbe. (2017) 21:297-300. doi: 10.1016/j.chom.2017.02.003

9. Netea MG, Joosten LA, Latz E, Mills KH, Natoli G, Stunnenberg HG, et al. Trained immunity: a program of innate immune memory in health and disease. Science. (2016) 352:aaf1098. doi: 10.1126/science.aaf1098

10. Yang J, James E, Gates TJ, DeLong JH, LaFond RE, Malhotra U, et al. CD4 ${ }^{+}$ $\mathrm{T}$ cells recognize unique and conserved 2009. H1N1 influenza hemagglutinin epitopes after natural infection and vaccination. Int Immunol. (2013) 25:44757. doi: 10.1093/intimm/dxt005

11. Schroeder T, Jørgensen LG, Knudsen L, Perko M. Haemodynamisk vurdering af det cerebrale kredsløb med transkranial doppler-ultralyd hos patienter med carotisstenose. Ugeskr Laeg. (1990) 152:2110-3.

12. Paquette SG, Huang SS, Banner D, Xu L, León A, Kelvin AA, et al. Impaired heterologous immunity in aged ferrets during sequential influenza a H1N1 infection. Virology. (2014) 464-5:177-83. doi: 10.1016/j.virol.2014.07.013

13. Guo J, Feng Y, Barnes P, Huang F-F, Idell S, Su D-M, et al. Deletion of FoxN1 in the thymic medullary epithelium reduces peripheral $\mathrm{T}$ cell responses to infection and mimics changes of aging. PLoS ONE. (2012) 7:e34681. doi: 10.1371/journal.pone.0034681

14. Josset L, Engelmann F, Haberthur K, Kelly S, Park B, Kawoaka Y, et al. Increased viral loads and exacerbated innate host responses in aged macaques infected with the 2009 pandemic H1N1 influenza A virus. J Virol. (2012) 86:11115-27. doi: 10.1128/JVI.01571-12

15. Muto NA, Sunden Y, Hattori T, Fujikura D, Nakayama Y, Miyazaki T, et al. Pathological examination of lung tissues in influenza A virus-infected mice. Jpn J Infect Dis. (2012) 65:383-91. doi: 10.7883/yoken.65.383

16. Pica N, Langlois RA, Krammer F, Margine I, Palese P. NS1-truncated live attenuated virus vaccine provides robust protection to aged mice from viral challenge. J Virol. (2012) 86:10293-301. doi: 10.1128/JVI.01131-12

17. Bender BS, Small PA. Heterotypic immune mice lose protection against influenza virus infection with senescence. J Infect Dis. (1993) 168:873-80. doi: 10.1093/infdis/168.4.873

18. Decman V, Laidlaw BJ, Dimenna LJ, Abdulla S, Mozdzanowska K, Erikson J, et al. Cell-intrinsic defects in the proliferative response of antiviral memory

\section{ACKNOWLEDGMENTS}

We would like to thank the European Society of Clinical Microbiology and Infectious Diseases (ESCMID) Study Group on Respiratory Viruses (ESGREV) for providing a platform for scientific discussion on the topic and Debbie Jordan for proofreading the manuscript.

CD8 T cells in aged mice upon secondary infection. J Immunol. (2010) 184:5151-9. doi: 10.4049/jimmunol.0902063

19. Pizzolla A, Wakim LM. Memory $\mathrm{T}$ cell dynamics in the lung during influenza virus infection. J Immunol. (2019) 202:374-81. doi: 10.4049/jimmunol.1800979

20. Zens KD, Chen JK, Farber DL. Vaccine-generated lung tissue-resident memory $\mathrm{T}$ cells provide heterosubtypic protection to influenza infection. JCI Insight. (2016) 1:e85832. doi: 10.1172/jci.insight.85832

21. Grant E, Wu C, Chan K-F, Eckle S, Bharadwaj M, Zou QM, et al. Nucleoprotein of influenza A virus is a major target of immunodominant CD8+ T-cell responses. Immunol Cell Biol. (2013) 91:184-94. doi: 10.1038/icb.2012.78

22. Gutiérrez AH, Rapp-Gabrielson VJ, Terry FE, Loving CL, Moise L, Martin WD, et al. T-cell epitope content comparison (EpiCC) of swine H1 influenza A virus hemagglutinin. Influenza Other Respir Viruses. (2017) 11:531-42. doi: 10.1111/irv.12513

23. Grant EJ, Josephs TM, Loh L, Clemens EB, Sant S, Bharadwaj M, et al. Broad $\mathrm{CD}^{+} \mathrm{T}$ cell cross-recognition of distinct influenza A strains in humans. Nat Commun. (2018) 9:5427. doi: 10.1038/s41467-018-07815-5

24. Wedemeyer H, Mizukoshi E, Davis AR, Bennink JR, Rehermann B. Cross-reactivity between hepatitis $C$ virus and influenza A virus determinant-specific cytotoxic T cells. J Virol. (2001) 75:11392-400. doi: 10.1128/JVI.75.23.11392-11400.2001

25. Urbani S, Amadei B, Fisicaro P, Pilli M, Missale G, Bertoletti A, et al. Heterologous T cell immunity in severe hepatitis C virus infection. J Exp Med. (2005) 201:675-80. doi: 10.1084/jem.20041058

26. Clute SC, Naumov YN, Watkin LB, Aslan N, Sullivan JL, Thorley-Lawson $\mathrm{DA}$, et al. Broad cross-reactive TCR repertoires recognizing dissimilar epstein-barr and influenza A virus epitopes. J Immunol. (2010) 185:6753-64. doi: 10.4049/jimmunol.1000812

27. Skevaki C, Hudemann C, Matrosovich M, Möbs C, Paul S, Wachtendorf $\mathrm{A}$, et al. Influenza-derived peptides cross-react with allergens and provide asthma protection. J Allergy Clin Immunol. (2018) 142:804-14. doi: $10.1016 / j . j a c i .2017 .07 .056$

28. Slon Campos JL, Mongkolsapaya J, Screaton GR. The immune response against flaviviruses. Nat Immunol. (2018) 19:1189-98. doi: 10.1038/s41590-018-0210-3

29. Elong Ngono A, Shresta S. Cross-reactive T cell immunity to dengue and zika viruses: new insights into vaccine development. Front Immunol. (2019) 10:1316. doi: 10.3389/fimmu.2019.01316

30. Grifoni A, Pham J, Sidney J, O'Rourke PH, Paul S, Peters B, et al. Prior dengue virus exposure shapes T cell immunity to zika virus in humans. J Virol. (2017) 91:e01469-17. doi: 10.1128/JVI.01469-17

31. Lim MQ, Kumaran EA, Tan HC, Lye DC, Leo YS, Ooi EE, et al. Cross-reactivity and anti-viral function of dengue capsid and NS3specific memory T cells toward zika virus. Front Immunol. (2018) 9:2225. doi: 10.3389/fimmu.2018.02225

32. Regla-Nava JA, Elong Ngono A, Viramontes KM, Huynh A-T, Wang Y$\mathrm{T}$, Nguyen A-VT, et al. Cross-reactive dengue virus-specific CD8 ${ }^{+} \mathrm{T}$ cells protect against zika virus during pregnancy. Nat Commun. (2018) 9:3042. doi: 10.1038/s41467-018-05458-0

33. Saron WA, Rathore AP, Ting L, Ooi EE, Low J, Abraham SN, et al. Flavivirus serocomplex cross-reactive immunity is protective by activating heterologous memory CD4 T cells. Sci Adv. (2018) 4:eaar4297. doi: 10.1126/sciadv.aar4297

34. Balamurugan A, Ng HL, Yang OO. Cross-reactivity against multiple HIV-1 epitopes is characteristic of HIV-1-specific cytotoxic T lymphocyte clones. $J$ Virol. (2018) 92:JVI.00617-18. doi: 10.1128/JVI.00617-18 
35. Vali B, Tohn R, Cohen MJ, Sakhdari A, Sheth PM, Yue FY, et al. Characterization of cross-reactive $\mathrm{CD}^{+}{ }^{+}$T-cell recognition of HLA-A2restricted HIV-Gag (SLYNTVATL) and HCV-NS5b (ALYDVVSKL) epitopes in individuals infected with human immunodeficiency and hepatitis $C$ viruses. J Virol. (2011) 85:254-63. doi: 10.1128/JVI.01743-10

36. Lanford RE, Guerra B, Chavez D, Bigger C, Brasky KM, Wang X-H, et al. Cross-genotype immunity to hepatitis C virus. J Virol. (2004) 78:1575-81. doi: 10.1128/JVI.78.3.1575-1581.2004

37. Prince AM, Brotman B, Lee D-H, Pfahler W, Tricoche N, Andrus L, et al. Protection against chronic hepatitis $\mathrm{C}$ virus infection after rechallenge with homologous, but not heterologous, genotypes in a chimpanzee model. J Infect Dis. (2005) 192:1701-9. doi: 10.1086/496889

38. Giugliano S, Oezkan F, Bedrejowski M, Kudla M, Reiser M, Viazov S, et al. Degree of cross-genotype reactivity of hepatitis $\mathrm{C}$ virus-specific CD8+ T cells directed against NS3. Hepatology. (2009) 50:707-16. doi: 10.1002/hep.23096

39. Ziegler S, Skibbe K, Walker A, Ke X, Heinemann FM, Heinold A, et al. Impact of sequence variation in a dominant HLA-A*02-restricted epitope in hepatitis $\mathrm{C}$ virus on priming and cross-reactivity of $\mathrm{CD}^{+}{ }^{+} \mathrm{T}$ cells. J Virol. (2014) 88:11080-90. doi: 10.1128/JVI.01590-14

40. Fytili P, Dalekos GN, Schlaphoff V, Suneetha PV, Sarrazin C, Zauner W, et al. Cross-genotype-reactivity of the immunodominant HCV CD8 T-cell epitope NS3-1073. Vaccine. (2008) 26:3818-26. doi: 10.1016/j.vaccine.2008.05.045

41. Antunes DA, Rigo MM, Silva JP, Cibulski SP, Sinigaglia M, Chies JA, et al. Structural in silico analysis of cross-genotype-reactivity among naturally occurring HCV NS3-1073-variants in the context of HLA-A*02:01 allele. Mol Immunol. (2011) 48:1461-7. doi: 10.1016/j.molimm.2011.03.019

42. Zhang S, Bakshi RK, Suneetha PV, Fytili P, Antunes DA, Vieira GF, et al. Frequency, private specificity, and cross-reactivity of preexisting hepatitis $\mathrm{C}$ virus ( $\mathrm{HCV}$ )-specific $\mathrm{CD}^{+} \mathrm{T}$ cells in $\mathrm{HCV}$-seronegative individuals: implications for vaccine responses. J Virol. (2015) 89:8304-17. doi: 10.1128/JVI.00539-15

43. Agrawal B, Singh S, Gupta N, Li W, Vedi S, Kumar R. Unsolved puzzles surrounding HCV immunity: heterologous immunity adds another dimension. Int J Mol Sci. (2017) 18:1626. doi: 10.3390/ijms18081626

44. Kennedy PT, Urbani S, Moses RA, Amadei B, Fisicaro P, Lloyd J, et al. The influence of $\mathrm{T}$ cell cross-reactivity on HCV-peptide specific human $\mathrm{T}$ cell response. Hepatology. (2006) 43:602-11. doi: 10.1002/hep.21081

45. Wei R, Yang C, Zeng M, Terry F, Zhu K, Yang C, et al. A dominant EV71specific $\mathrm{CD} 4^{+} \mathrm{T}$ cell epitope is highly conserved among human enteroviruses. PLoS ONE. (2012) 7:e51957. doi: 10.1371/journal.pone.0051957

46. Gern JE, Dick EC, Kelly EA, Vrtis R, Klein B. Rhinovirus-specific T cells recognize both shared and serotype-restricted viral epitopes. J Infect Dis. (1997) 175:1108-14. doi: 10.1086/516449

47. Muehling LM, Mai DT, Kwok WW, Heymann PW, Pomés A, Woodfolk JA. Circulating memory $\mathrm{CD} 4^{+} \mathrm{T}$ cells target conserved epitopes of rhinovirus capsid proteins and respond rapidly to experimental infection in humans. $J$ Immunol. (2016) 197:3214-24. doi: 10.4049/jimmunol.1600663

48. Zhao J, Zhao J, Mangalam AK, Channappanavar R, Fett C, Meyerholz $\mathrm{DK}$, et al. Airway memory $\mathrm{CD} 4(+) \mathrm{T}$ cells mediate protective immunity against emerging respiratory coronaviruses. Immunity. (2016) 44:1379-91. doi: 10.1016/j.immuni.2016.05.006

49. Gisa A, Suneetha PV, Behrendt P, Pischke S, Bremer B, Falk CS, et al. Crossgenotype-specific T-cell responses in acute Hepatitis E Virus (HEV) infection. J Viral Hepat. (2016) 23:305-15. doi: 10.1111/jvh.12495

50. Daniels KA, Hatfield SD, Welsh RM, Brehm MA. MHC basis of T celldependent heterologous immunity to arenaviruses. Virology. (2014) 4645:213-7. doi: 10.1016/j.virol.2014.07.012

51. Duangchinda T, Dejnirattisai W, Vasanawathana S, Limpitikul W, Tangthawornchaikul N, Malasit P, et al. Immunodominant T-cell responses to dengue virus NS3 are associated with DHF. Proc Natl Acad Sci USA. (2010) 107:16922-7. doi: 10.1073/pnas.1010867107

52. Mangada MM, Endy TP, Nisalak A, Chunsuttiwat S, Vaughn DW, Libraty DH, et al. Dengue-specific $\mathrm{T}$ cell responses in peripheral blood mononuclear cells obtained prior to secondary dengue virus infections in Thai schoolchildren. $J$ Infect Dis. (2002) 185:1697-703. doi: 10.1086/340822

53. Wijeratne DT, Fernando S, Gomes L, Jeewandara C, Ginneliya A, Samarasekara S, et al. Quantification of dengue virus specific $\mathrm{T}$ cell responses and correlation with viral load and clinical disease severity in acute dengue infection. PLoS Negl Trop Dis. (2018) 12:e0006540. doi: 10.1371/journal.pntd.0006540

54. Simon-Lorière E, Duong V, Tawfik A, Ung S, Ly S, Casadémont I, et al. Increased adaptive immune responses and proper feedback regulation protect against clinical dengue. Sci Transl Med. (2017) 9:eaal5088. doi: $10.1126 /$ scitranslmed.aal 5088

55. Aaby P, Martins CL, Garly M-L, Rodrigues A, Benn CS, Whittle H. The optimal age of measles immunisation in low-income countries: a secondary analysis of the assumptions underlying the current policy. BMJ Open. (2012) 2:e000761. doi: 10.1136/bmjopen-2011-000761

56. Aaby P, Samb B, Simondon F, Seck AM, Knudsen K, Whittle H. Non-specific beneficial effect of measles immunisation: analysis of mortality studies from developing countries. BMJ. (1995) 311:481-5. doi: 10.1136/bmj.311.7003.481

57. Aaby P, Bhuiya A, Nahar L, Knudsen K, Francisco A de, Strong M. The survival benefit of measles immunization may not be explained entirely by the prevention of measles disease: a community study from rural Bangladesh. Int J Epidemiol. (2003) 32:106-16. doi: 10.1093/ije/dyg005

58. Aaby P, Biai S, Veirum JE, Sodemann M, Lisse I, Garly M-L, et al. DTP with or after measles vaccination is associated with increased in-hospital mortality in Guinea-Bissau. Vaccine. (2007) 25:1265-9. doi: 10.1016/j.vaccine.2006.10.007

59. Blok BA, Arts RJ, van Crevel R, Benn CS, Netea MG. Trained innate immunity as underlying mechanism for the long-term, nonspecific effects of vaccines. $J$ Leukoc Biol. (2015) 98:347-56. doi: 10.1189/jlb.5RI0315-096R

60. Jensen KJ, Benn CS, van Crevel R. Unravelling the nature of non-specific effects of vaccines-A challenge for innate immunologists. Semin Immunol. (2016) 28:377-83. doi: 10.1016/j.smim.2016.05.005

61. Higgins JP, Soares-Weiser K, Reingold A. Systematic Review of the NonSpecific Effects of BCG, DTP and Measles Containing Vaccines. (2014). Available online at: https://www.who.int/immunization/sage/meetings/2014/ april/3_NSE_Epidemiology_review_Report_to_SAGE_14_Mar_FINAL.pdf

62. Higgins JP, Soares-Weiser K, López-López JA, Kakourou A, Chaplin K, Christensen H, et al. Association of BCG, DTP, and measles containing vaccines with childhood mortality: systematic review. BMJ. (2016) 355:15170. doi: 10.1136/bmj.i5170

63. Aaby P, Roth A, Ravn H, Napirna BM, Rodrigues A, Lisse IM, et al. Randomized trial of BCG vaccination at birth to low-birth-weight children: beneficial nonspecific effects in the neonatal period? J Infect Dis. (2011) 204:245-52. doi: 10.1093/infdis/jir240

64. Aaby P, Gustafson P, Roth A, Rodrigues A, Fernandes M, Sodemann $\mathrm{M}$, et al. Vaccinia scars associated with better survival for adults. An observational study from Guinea-Bissau. Vaccine. (2006) 24:5718-25. doi: $10.1016 /$ j.vaccine.2006.04.045

65. Villumsen M, Sørup S, Jess T, Ravn H, Relander T, Baker JL, et al. Risk of lymphoma and leukaemia after bacille calmette-guérin and smallpox vaccination: a Danish case-cohort study. Vaccine. (2009) 27:6950-8. doi: 10.1016/j.vaccine.2009.08.103

66. Sørup S, Benn CS, Poulsen A, Krause TG, Aaby P, Ravn H. Live vaccine against measles, mumps, and rubella and the risk of hospital admissions for nontargeted infections. JAMA. (2014) 311:826-35. doi: $10.1001 /$ jama.2014.470

67. Fish EN, Flanagan KL, Furman D, Klein SL, Kollmann TR, Jeppesen DL, et al. Changing oral vaccine to inactivated polio vaccine might increase mortality. Lancet. (2016) 387:1054-5. doi: 10.1016/S0140-6736(16)00661-9

68. Aaby P, Rodrigues A, Biai S, Martins C, Veirum JE, Benn CS, et al. Oral polio vaccination and low case fatality at the paediatric ward in Bissau, Guinea-Bissau. Vaccine. (2004) 22:3014-7. doi: 10.1016/j.vaccine.2004.02.009

69. Andersen A, Fisker AB, Rodrigues A, Martins C, Ravn H, Lund N, et al. National immunization campaigns with oral polio vaccine reduce all-cause mortality: a natural experiment within seven randomized trials. Front Public Health. (2018) 6:13. doi: 10.3389/fpubh.2018.00013

70. Frankild S, Boer RJ de, Lund O, Nielsen M, Kesmir C. Amino acid similarity accounts for T cell cross-reactivity and for "holes" in the T cell repertoire. PLoS ONE. (2008) 3:e1831. doi: 10.1371/journal.pone.0001831

71. Benn CS, Netea MG, Selin LK, Aaby P. A small jab - a big effect: nonspecific immunomodulation by vaccines. Trends Immunol. (2013) 34:4319. doi: 10.1016/j.it.2013.04.004

72. Aaby P, Benn C, Nielsen J, Lisse IM, Rodrigues A, Ravn H. Testing the hypothesis that diphtheria-tetanus-pertussis vaccine has negative non-specific 
and sex-differential effects on child survival in high-mortality countries. $B M J$ Open. (2012) 2:e000707. doi: 10.1136/bmjopen-2011-000707

73. Freyne B, Donath S, Germano S, Gardiner K, Casalaz D, Robins-Browne RM, et al. Neonatal BCG vaccination influences cytokine responses to toll-like receptor ligands and heterologous antigens. J Infect Dis. (2018) 217:1798-808. doi: 10.1093/infdis/jiy069

74. Nissen TN, Birk NM, Blok BA, Arts RJ, Andersen A, Kjærgaard J, et al. Bacillus calmette-guérin vaccination at birth and in vitro cytokine responses to nonspecific stimulation. A randomized clinical trial. Eur J Clin Microbiol Infect Dis. (2018) 37:29-41. doi: 10.1007/s10096-017-3097-2

75. Aaby P, Jensen H, Walraven G. Age-specific changes in the femalemale mortality ratio related to the pattern of vaccinations: an observational study from rural Gambia. Vaccine. (2006) 24:4701-8. doi: $10.1016 /$ j.vaccine. 2006.03 .038

76. Noho-Konteh F, Adetifa JU, Cox M, Hossin S, Reynolds J, Le MT, et al. Sex-differential non-vaccine-specific immunological effects of diphtheriatetanus-pertussis and measles vaccination. Clin Infect Dis. (2016) 63:1213-26. doi: 10.1093/cid/ciw492

77. Ndure J, Noho-Konteh F, Adetifa JU, Cox M, Barker F, Le MT, et al. Negative correlation between circulating $\mathrm{CD} 4{ }^{+} \mathrm{FOXP}^{+}{ }^{+} \mathrm{CD} 127^{-}$regulatory $\mathrm{T}$ cells and subsequent antibody responses to infant measles vaccine but not diphtheriatetanus-pertussis vaccine implies a regulatory role. Front Immunol. (2017) 8:921. doi: 10.3389/fimmu.2017.00921

78. Samb B, Whittle H, Aaby P, Seck AM, Bennett J, Markowitz L, et al. No evidence of long-term immunosuppression after high-titer edmonstronzagreb measles vaccination in Senegal. J Infect Dis. (1995) 171:506-8. doi: 10.1093/infdis/171.2.506

79. Lisse IM, Aaby P, Knudsen K, Whittle H, Andersen H. Long term impact of high titer edmonston-zagreb measles vaccine on T lymphocyte subsets. Pediatr Infect Dis J. (1994) 13:109-12. doi: 10.1097/00006454-199402000-00006

80. León ME, Ward B, Kanashiro R, Hernández H, Berry S, Vaisberg A, et al. Immunologic parameters 2 years after high-titer measles immunization in Peruvian children. J Infect Dis. (1993) 168:1097-104. doi: $10.1093 /$ infdis/168.5.1097
81. Bekkering S, van den Munckhof I, Nielen T, Lamfers E, Dinarello C, Rutten J, et al. Innate immune cell activation and epigenetic remodeling in symptomatic and asymptomatic atherosclerosis in humans in vivo. Atherosclerosis. (2016) 254:228-36. doi: 10.1016/j.atherosclerosis.2016.10.019

82. Novakovic B, Messina NL, Curtis N. The heterologous effects of bacillus calmette-guérin (BCG) vaccine and trained innate immunity. In: Faustman D, editor. The Value of BCG and TNF in Autoimmunity. London, UK; San Diego, CA: Academic Press (2018). p. 71-90.

83. Krone B, Kölmel KF, Grange JM, Mastrangelo G, Henz BM, Botev IN, et al. Impact of vaccinations and infectious diseases on the risk of melanomaevaluation of an EORTC case-control study. Euro J Cancer. (2003) 39:2372-8. doi: 10.1016/S0959-8049(03)00625-7

84. Boisgerault N, Guillerme J-B, Pouliquen D, Mesel-Lemoine M, Achard C, Combredet $\mathrm{C}$, et al. Natural oncolytic activity of live-attenuated measles virus against human lung and colorectal adenocarcinomas. Biomed Res Int. (2013) 2013:387362. doi: 10.1155/2013/387362

85. Bree LC de, Koeken VA, Joosten LA, Aaby P, Benn CS, van Crevel R, et al. Non-specific effects of vaccines: current evidence and potential implications. Semin Immunol. (2018) 39:35-43. doi: 10.1016/j.smim.2018.06.002

Conflict of Interest: For CS: Consultancy and research funding, Hycor Biomedical and Thermo Fisher Scientific; Consultancy, Bencard Allergie; Research Funding, Mead Johnson Nutrition (MJN).

The remaining authors declare that the research was conducted in the absence of any commercial or financial relationships that could be construed as a potential conflict of interest.

Copyright $\odot 2020$ Balz, Trassl, Härtel, Nelson and Skevaki. This is an open-access article distributed under the terms of the Creative Commons Attribution License (CC $B Y)$. The use, distribution or reproduction in other forums is permitted, provided the original author(s) and the copyright owner(s) are credited and that the original publication in this journal is cited, in accordance with accepted academic practice. No use, distribution or reproduction is permitted which does not comply with these terms. 